Vol 14, Issue 4, 2021

\title{
EFFECTS OF PH AND AMOUNT OF ACETONITRILE ON THE SEPARATION OF CANNABINOIDS
}

\author{
EVA TEJADA, JANIS VELLA SZIJJ*, MIRIANA CACHIA, PAULINE FALZON, LILIAN M AZZOPARDI, \\ ANTHONY SERRACINO INGLOTT
}

Department of Pharmacy, Faculty of Medicine and Surgery, University of Malta, Msida, Malta MSD 2080, Malta.

Email: janis.vella@um.edu.mt

Received: 20 January 2021, Revised and Accepted: 01 March 2021

ABSTRACT

Objective: During reversed-phase high-performance liquid chromatography (HPLC) analyses, optimization of separation can be achieved by selecting appropriate chromatographic conditions. The retention time, peak shape, and peak size of chromatographic peaks are dependent on amount of organic modifier in the mobile phase and buffer $\mathrm{pH}$. The aim of this study was to investigate the effects of varying $\mathrm{pH}$, acetonitrile composition and flow rate of the mobile phase, and temperature of the stationary phase and wavelength in the development of a method to separate $\Delta 9$ tetrahydrocannabinol, cannabidiol, and cannabinol.

Methods: Mobile phases with different buffer pHs and acetonitrile composition were used with ultraviolet (UV) detection wavelength of 220 nm and $228 \mathrm{~nm}$. The AUPs and retention times were observed using different mobile phase flow rates and stationary phase temperatures.

Results: The best results were obtained when using a mobile phase composition of $20 \%$ phosphate buffer $\mathrm{pH} 2.5$ or $\mathrm{pH} 3$ and $80 \%$ acetonitrile v/v at a flow rate of $2 \mathrm{~mL} / \mathrm{min}$ at $220 \mathrm{~nm}$.

Conclusion: This rapid and easy-to-use HPLC method describes the effect of changing important chromatographic parameters on separation and retention time of cannabinoids and can be effectively applied for high throughput analysis.

Keywords: Reversed-phase high-performance liquid chromatography, $\mathrm{pH}$, Acetonitrile, $\Delta 9$ tetrahydrocannabinol, Cannabidiol, Cannabinol.

(C) 2021 The Authors. Published by Innovare Academic Sciences Pvt Ltd. This is an open access article under the CC BY license (http://creativecommons.org/ licenses/by/4.0/) DOI: http://dx.doi.org/10.22159/ajpcr.2021v14i4.40844. Journal homepage: https://innovareacademics.in/journals/index.php/ajpcr

\section{INTRODUCTION}

Reversed-phase high-performance liquid chromatography (RP-HPLC) separates analytes based on differences in polarity [1] and is the most commonly used type of liquid chromatographic analytical technique, preferred by the pharmaceutical industry [2,3]. When developing analytical HPLC methods, various parameters have to be considered to achieve favorable resolution, specificity, peak shape, retention time, and total run time [4,5]. Different detectors such as ultraviolet (UV), fluorescence, and mass spectrometry (MS) can be coupled to HPLC. MS detectors have very good sensitivity and selectivity but require skilled expertise to operate and are relatively expensive. UV detectors are often preferred as they are easier to operate, cheaper, and more readily available [6-8].

Optimization of separation of analytes can be achieved by selecting appropriate stationary phase and mobile phase characteristics and appropriate UV detection wavelength. Shorter retention times may be achieved with an increase in temperature of the stationary phase although stationary phase stability can be compromised if temperatures are too high $[9,10]$. The type and amount of organic modifier, $\mathrm{pH}$ of buffer, and flow rate of the mobile phase have an effect on peak shape, retention time, and resolution [11-14]. Chromatographic run times should ideally not be too long for more efficient analyses but not too short so as to compromise resolution and selectivity [15].

The majority of reversed-phase chromatographic analyses operate at $\mathrm{pH}$ values in the range of 2-8 [16]. Control of $\mathrm{pH}$ of the buffer used in the mobile phase is important when separating analytes can be ionized. $\mathrm{pH}$ control can affect symmetry and peak shape which is enhanced when the analytes are present in either an ionized or unionized form. Ionization also affects relative distribution of analytes between mobile and stationary phase, influencing retention time in the process. Phosphate buffers are widely used in HPLC analyses as they are inexpensive, produce good chromatograms, and can be used for a range of $\mathrm{pH}$ values since phosphoric acid has three different buffering ranges: $\mathrm{pH}$ 1.1-3.1, $\mathrm{pH}$ 6.2-8.2, and $\mathrm{pH}$ 11.3-13.3 [15]. Methanol and acetonitrile are the most commonly used buffers in isocratic reversedphase HPLC. Acetonitrile produces less of an increase in pressure and shorter run times when compared to methanol $[17,18]$.

The versatility of HPLC allows for the identification and quantification of a variety of compounds, both of natural and synthetic origin. HPLC can be effectively used to analyze compounds which present in the cannabis plant. Cannabis sativa is a dioecious plant belonging to the Cannabaceae family and has been used for millennia for recreational purposes, as a folk medicine and as a source of textile fiber [19-21]. Following a renewed interest in the properties of the cannabis plant after the description of cannabinoid receptors and the endogenous endocannabinoid system [22], efforts are now being put in trials and research on cannabis for medicinal purposes such as management of epilepsy, pain, and chemotherapy-induced nausea and vomiting [23-25]. The three most commonly studied cannabinoids known to exert physiological effects are $\Delta 9$ tetrahydrocannabinol (THC), cannabidiol (CBD), and cannabinol (CBN) [26-28] (Fig. 1).

THC, CBD, and CBN are weakly acidic compounds having pKa values of $10.5,9.5$, and 9.32, respectively [29,30]. At $\mathrm{pH}$ values lower than 9.32, THC, CBD, and CBN exist in their protonated form.

A number of chromatographic techniques describing the separation and determination of cannabinoids have been described with reversed-phase HPLC being commonly used for analysis [27,31-33]. Analysis of cannabinoids using HPLC allows for the determination of both neutral and acidic forms of cannabinoids without the need for derivatization [34]. HPLC methods using gradient and elution modes 


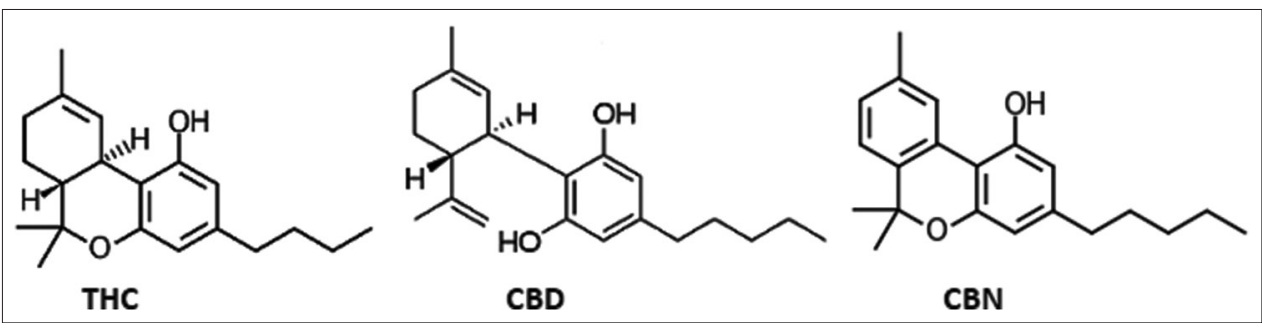

Fig. 1: Molecular structure of tetrahydrocannabinol, cannabidiol, and cannabinol

for the separation of cannabinoids have been described with isocratic elution being favored due to lower cost, ease of use, and no need of column re-equilibration between runs [35-38].

The aim of the study was to investigate the effects of varying $\mathrm{pH}$, acetonitrile composition and flow rate of the mobile phase, and temperature of the stationary phase and wavelength in the development of a comparatively simple and rapid method to separate THC, CBD, and CBN.

\section{METHODS}

\section{Mobile phases}

Mobile phases were prepared using HPLC-grade acetonitrile (Fisher Chemical, Leicestershire, UK) and phosphate buffer. The buffer was prepared by dissolving anhydrous extra pure disodium hydrogen phosphate (Scharlau, Sentmenat, Spain) in HPLC-grade water (Fisher Chemical, Leicestershire, UK) to make up a solution of $0.02 \mathrm{M}$, and $\mathrm{pH}$ was then adjusted by the dropwise addition of HPLC-grade orthophosphoric acid (Fisher Chemical, Leicestershire, UK). pH readings were taken using a Mettler Toledo FiveGo ${ }^{\circledR} \mathrm{pH}$ meter which was calibrated before every reading using standard Hanna ${ }^{\circledR}$ calibrator buffer solutions at $\mathrm{pH}$ values of 4.01 and 7.01. Twelve different mobile phases were used (Table 1).

\section{Sample preparation}

Standards of (-)-delta 9-THC $0.1 \mathrm{mg} / \mathrm{mL}$ in methanol, (-)-CBD $1.0 \mathrm{mg} / \mathrm{mL}$, and CBN $1.0 \mathrm{mg} / \mathrm{mL}$ were purchased from LGC Standards $\mathrm{GmBH}$ (Wesel, Germany). Stock solutions of $5 \mu \mathrm{g} / \mathrm{mL}$ of THC, CBD, and CBN were prepared in HPLC-grade methanol (Fisher Chemical, Leicestershire, UK). Equal volumes of the $5 \mu \mathrm{g} / \mathrm{mL}$ stock solutions of $\mathrm{THC}, \mathrm{CBD}$, and CBN were mixed in amber-colored flasks.

\section{Instrumentation}

An Agilent 1260 Infinity Series ${ }^{\circledast}$ liquid chromatographic system having a quaternary pump and multiwavelength detector was used. The stationary phase used was an $\mathrm{ACE}^{\circledR} \mathrm{RP} \mathrm{C}_{18}$ column $(250 \mathrm{~mm} \times 4.6 \mathrm{~mm}$; $5 \mu \mathrm{m}$ particle size). The temperature of the stationary phase was first set at $25^{\circ} \mathrm{C}$. The UV/visible detector was set at $220 \mathrm{~nm}$ and $228 \mathrm{~nm}$. Sample volumes of $20 \mu \mathrm{L}$ containing THC, CBD, and CBN were injected. Before analysis, solutions containing only THC, CBD, and CBN, respectively, were injected to assist with peak identification. Three replicate runs using each type of mobile phase prepared were carried out to ensure precision. Column equilibration was carried out before changing the mobile phase. The flow rate of the mobile phase was set at $1 \mathrm{~mL} / \mathrm{min}$. The best mobile phase characteristics according to amount of acetonitrile and $\mathrm{pH}$ were identified and then tested at two other different flow rates - of 1.5 and $2 \mathrm{~mL} / \mathrm{min}$. Following the choice of the flow rate which gave the best results in terms of resolution and speed of analysis, the temperature of the stationary phase was tested at two other different temperatures, namely $20^{\circ} \mathrm{C}$ and $30^{\circ} \mathrm{C}$, and the temperature giving the best results in terms of resolution and speed of analysis was chosen.

The run times were adjusted for each chromatogram according to the mobile phase used. The average values for the areas under the peak, area percentages, and retention times were calculated for each run.
Table 1: Properties of the mobile phases used for high-performance liquid chromatography separation of cannabinoids

\begin{tabular}{lll}
\hline $\begin{array}{l}\text { Mobile phase } \\
\text { number }\end{array}$ & $\begin{array}{l}\text { pH of } \\
\text { buffer }\end{array}$ & $\begin{array}{l}\text { Percentage of acetonitrile } \\
\text { in mobile phase }\end{array}$ \\
\hline 1 & 2.5 & 70 \\
2 & 2.5 & 80 \\
3 & 2.5 & 90 \\
4 & 3.0 & 70 \\
5 & 3.0 & 80 \\
6 & 3.0 & 90 \\
7 & 4.0 & 70 \\
8 & 4.0 & 80 \\
9 & 4.0 & 90 \\
10 & 6.0 & 70 \\
11 & 6.0 & 80 \\
12 & 6.0 & 90 \\
\hline
\end{tabular}

\section{RESULTS}

\section{Wavelength of analysis}

Larger areas under the peak were obtained for CBD, CBN, and THC at $220 \mathrm{~nm}$ when compared to $228 \mathrm{~nm}$. The areas under the peak for CBD and CBN were larger than the peak for THC for equal concentrations $(5 \mu \mathrm{g} / \mathrm{mL})$ of the three cannabinoids.

\section{Buffer pH}

There was no difference in peak shape or area under the peak when $\mathrm{pH} 2.5$ buffer and $\mathrm{pH} 3$ buffer were used. As the buffer $\mathrm{pH}$ was increased to 4 and 6 , there were some irregularities in the baseline although this did not affect the shape and area under the peak of the three cannabinoids (Figs. 2-9).

\section{Percentage of acetonitrile in the mobile phase}

As the amount of acetonitrile in the mobile phase was increased from $70 \%$ to $80 \%$, the retention time of the three cannabinoids decreased (Figs. 5 and 6). The retention time continued to decrease as the amount of acetonitrile was increased to $90 \%$, but the peak shape of CBD was compromised and unsymmetrical. The decrease in retention time with a loss of symmetry of peak occurred at all pH values - 2.5, 3, 4, and 6 (Figs. 10-13).

\section{Flow rate of mobile phase}

The mobile phase having a buffer $\mathrm{pH}$ of 2.5 and $80 \%$ acetonitrile was chosen as it gave favorable results in terms of peak shape, size, and retention time. As the flow rate of the mobile phase was increased from 1 to 1.5 to $2 \mathrm{~mL} / \mathrm{min}$, the total run time for the analysis of the three cannabinoids decreased from 14.3 to 9.4 to $7.0 \mathrm{~min}$, respectively (Figs. $6,14$ and 15$)$.

\section{Column temperature}

There was no difference in the areas under the peak or retention time of CBD, CBN, and THC when the column temperature was changed from $25^{\circ} \mathrm{C}$ to $20^{\circ} \mathrm{C}$ and $30^{\circ} \mathrm{C}$

\section{DISCUSSION}

Published UV spectra of cannabinoids have shown maximum UV absorption for THC, CBD, and CBN to lie in the region of around 


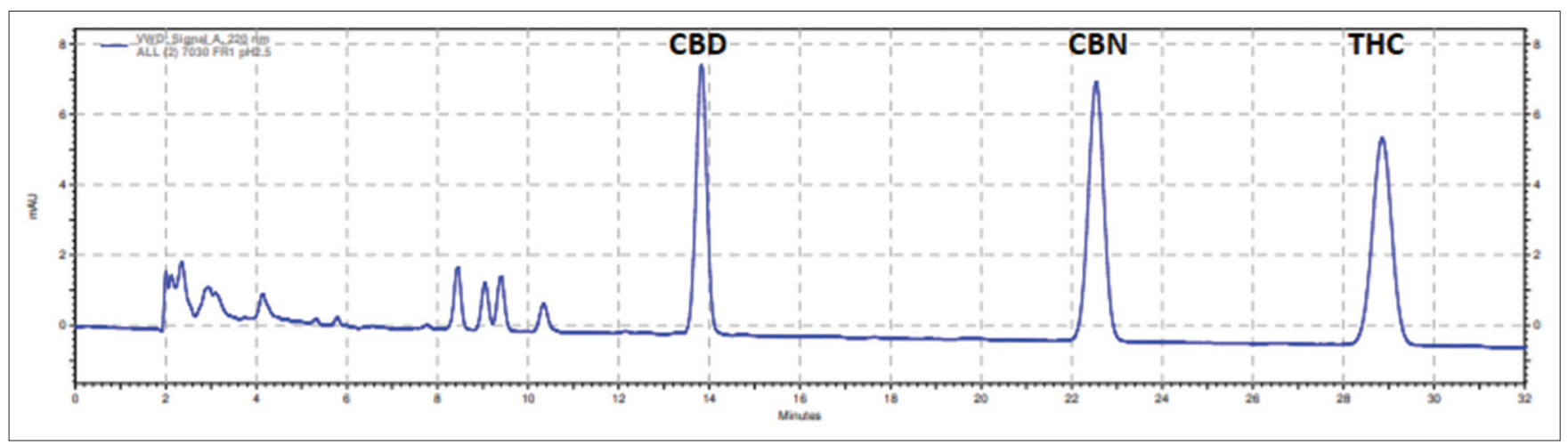

Fig. 2: Chromatogram produced using phosphate buffer ( $\mathrm{pH} 2.5$ ) and acetonitrile (30:70 v/v); detection wavelength $220 \mathrm{~nm}$; flow rate $1 \mathrm{~mL} / \mathrm{min}$

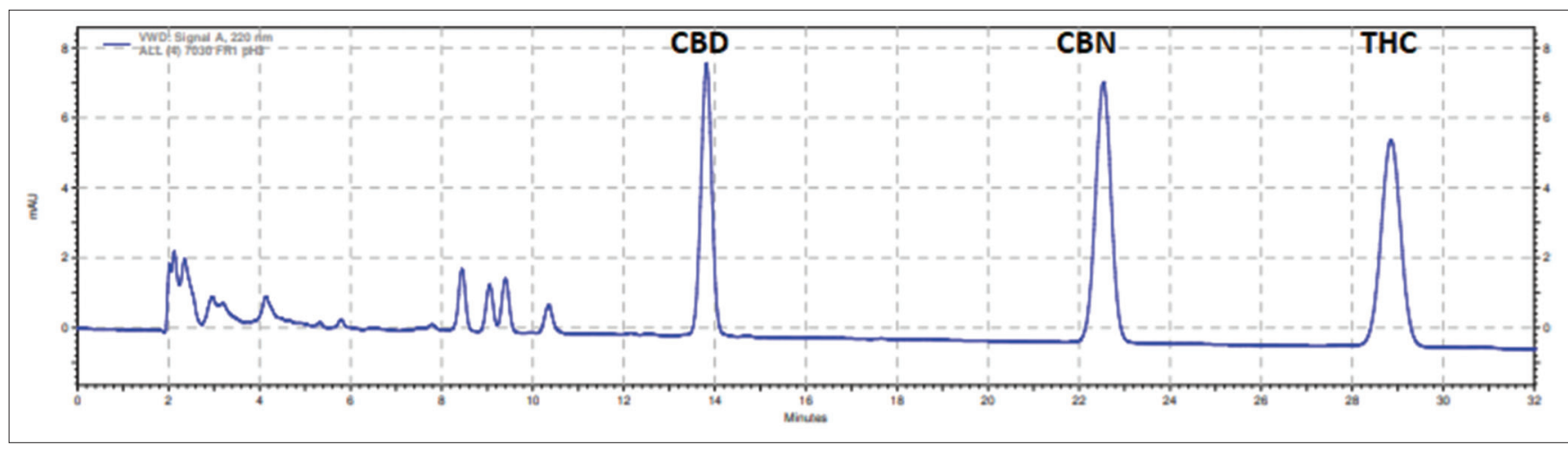

Fig. 3: Chromatogram produced using phosphate buffer (pH 3) and acetonitrile (30:70 v/v); detection wavelength 220nm; flow rate $1 \mathrm{~mL} / \mathrm{min}$

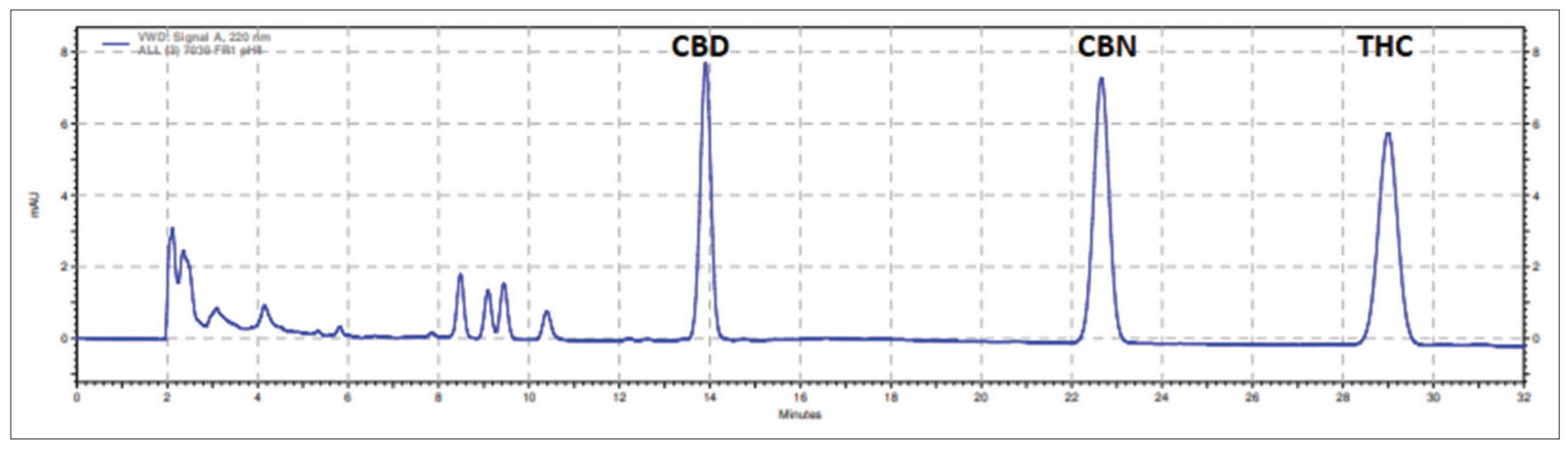

Fig. 4: Chromatogram produced using phosphate buffer ( $\mathrm{pH} 4$ ) and acetonitrile (30:70 v/v); detection wavelength 220 nm; flow rate $1 \mathrm{~mL} / \mathrm{min}$

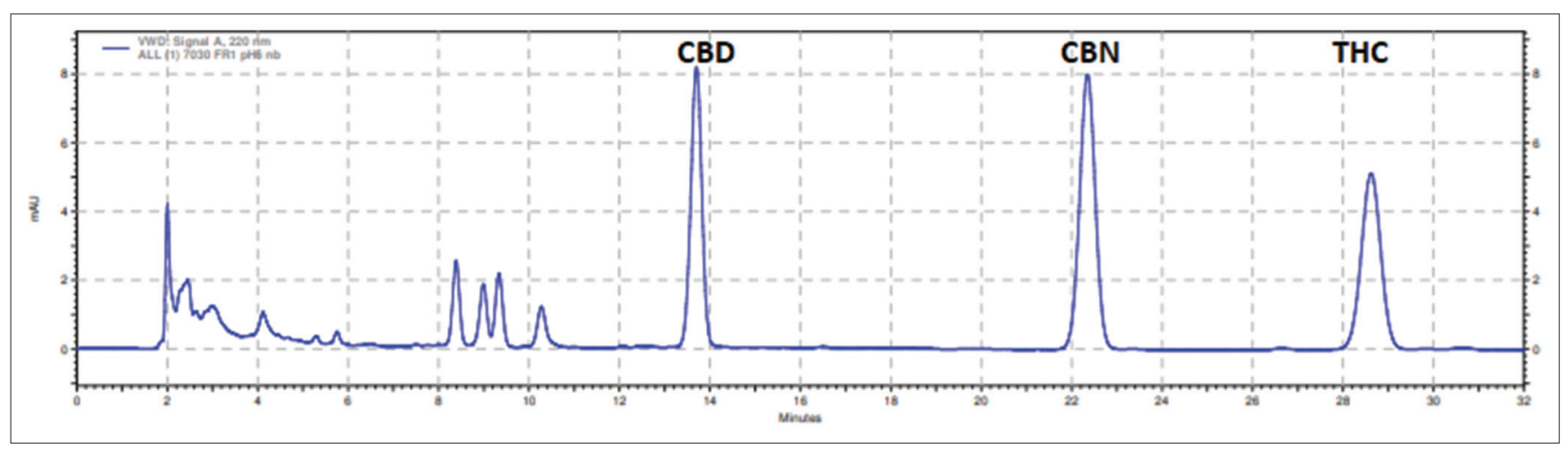

Fig. 5: Chromatogram produced using phosphate buffer (pH 6) and acetonitrile (30:70 v/v); detection wavelength $220 \mathrm{~nm}$; flow rate $1 \mathrm{~mL} / \mathrm{min}$ 


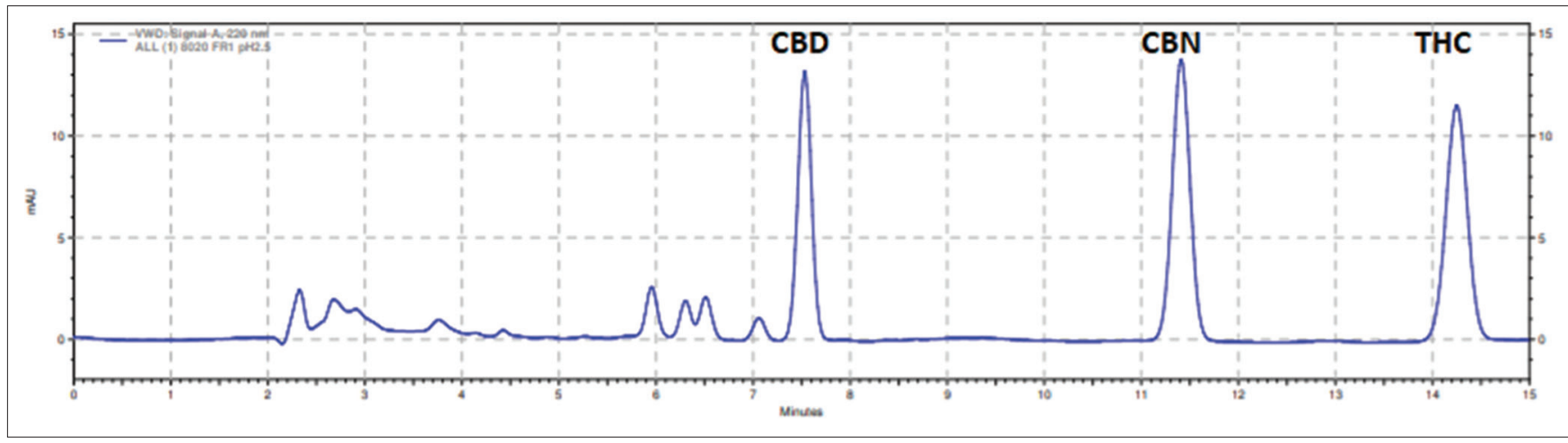

Fig. 6: Chromatogram produced using phosphate buffer (pH2.5) and acetonitrile (20:80 v/v); detection wavelength 220nm; flow rate $1 \mathrm{~mL} / \mathrm{min}$

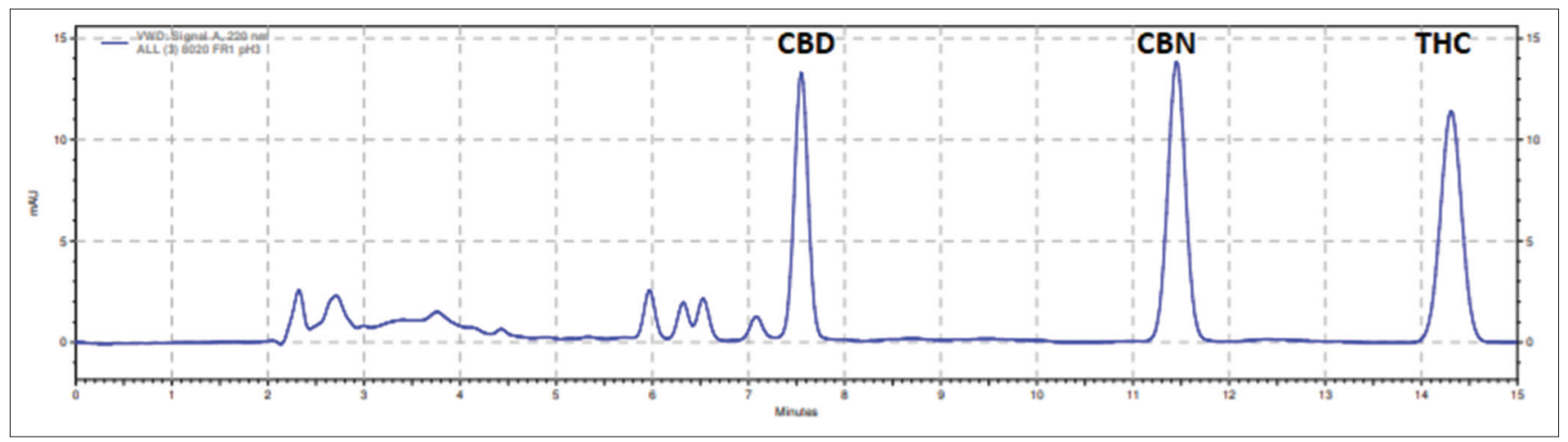

Fig. 7: Chromatogram produced using phosphate buffer (pH 3) and acetonitrile (20:80 v/v); detection wavelength 220nm; flow rate $1 \mathrm{~mL} / \mathrm{min}$

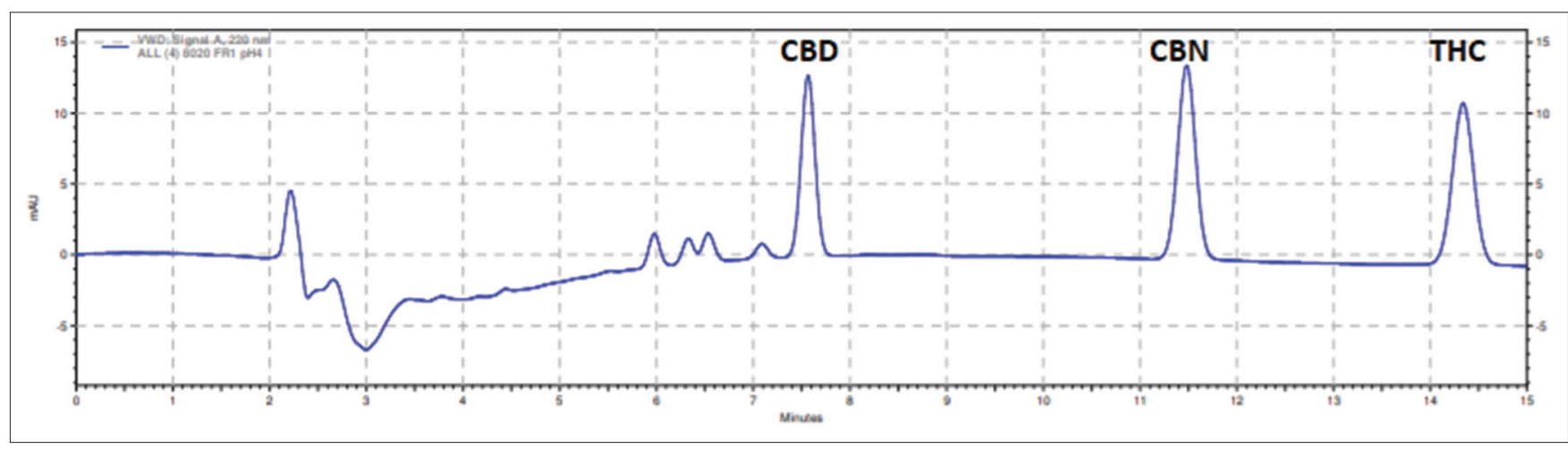

Fig. 8: Chromatogram produced using phosphate buffer (pH 4) and acetonitrile (20:80 v/v); detection wavelength 220 nm; flow rate $1 \mathrm{~mL} / \mathrm{min}$

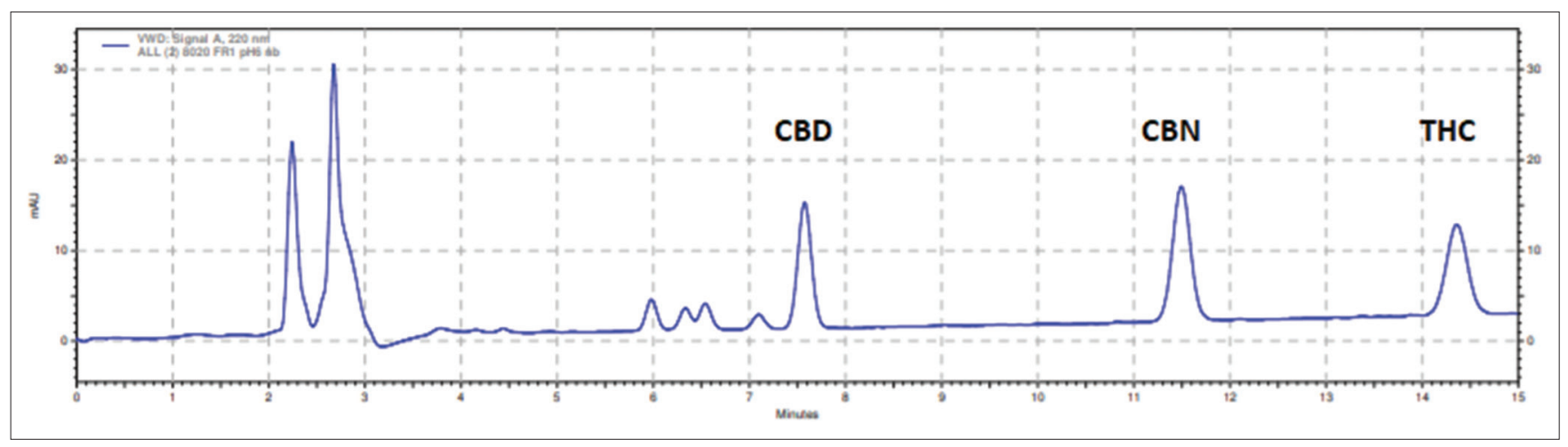

Fig. 9: Chromatogram produced using phosphate buffer (pH 6) and acetonitrile (20:80 v/v); detection wavelength $220 \mathrm{~nm}$; flow rate $1 \mathrm{~mL} / \mathrm{min}$ 


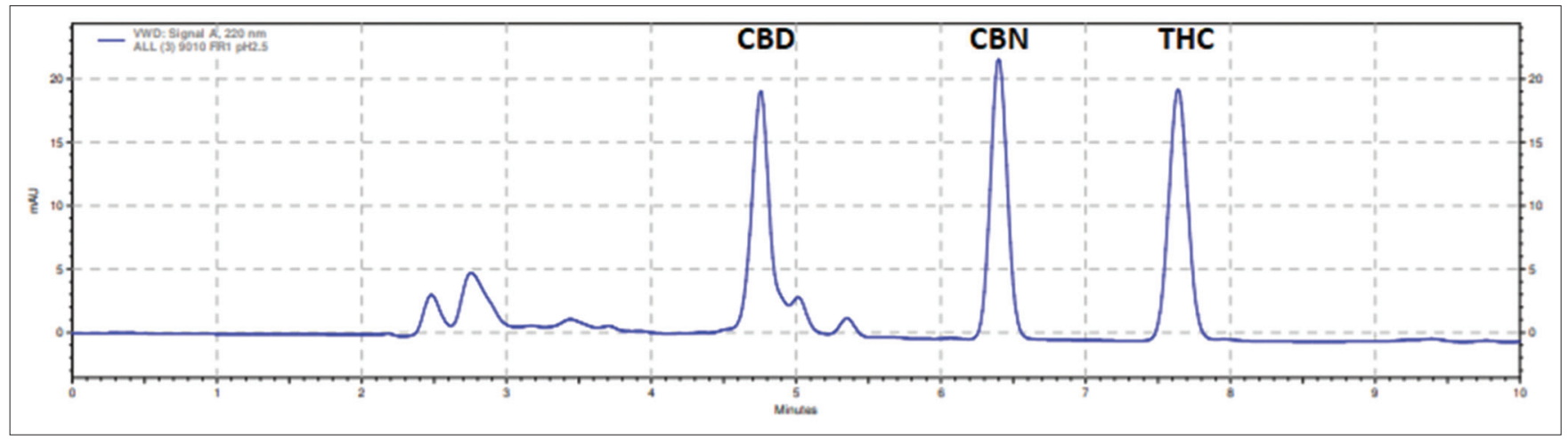

Fig. 10: Chromatogram produced using phosphate buffer ( $\mathrm{pH} 2.5)$ and acetonitrile (10:90 v/v); detection wavelength $220 \mathrm{~nm}$; flow rate $1 \mathrm{~mL} / \mathrm{min}$

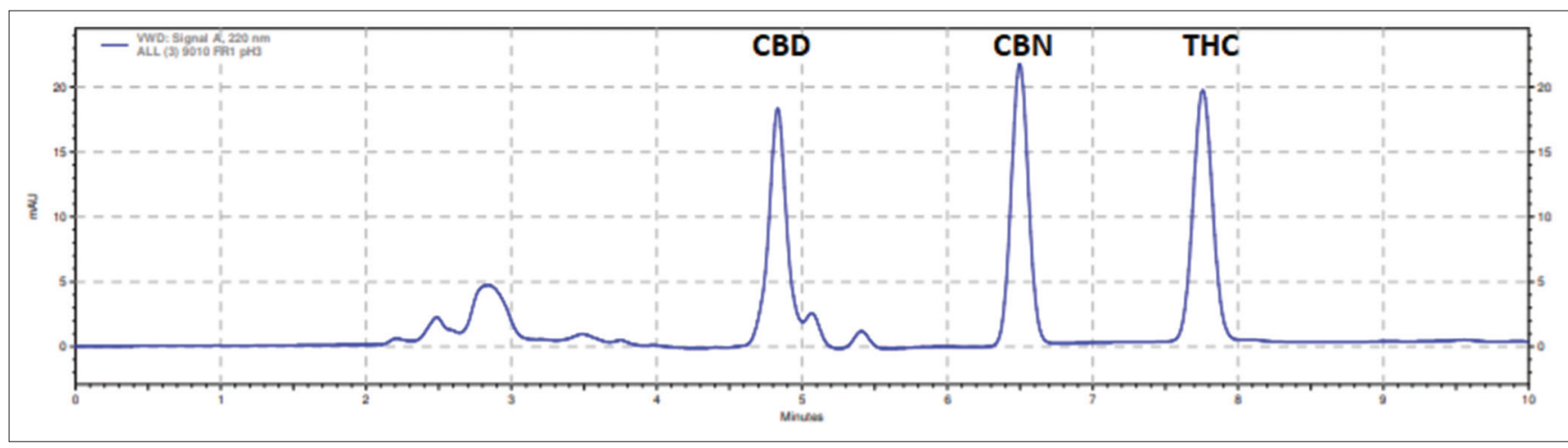

Fig. 11: Chromatogram produced using phosphate buffer $(\mathrm{pH} 3)$ and acetonitrile (10:90 v/v); detection wavelength $220 \mathrm{~nm}$; flow rate $1 \mathrm{~mL} / \mathrm{min}$

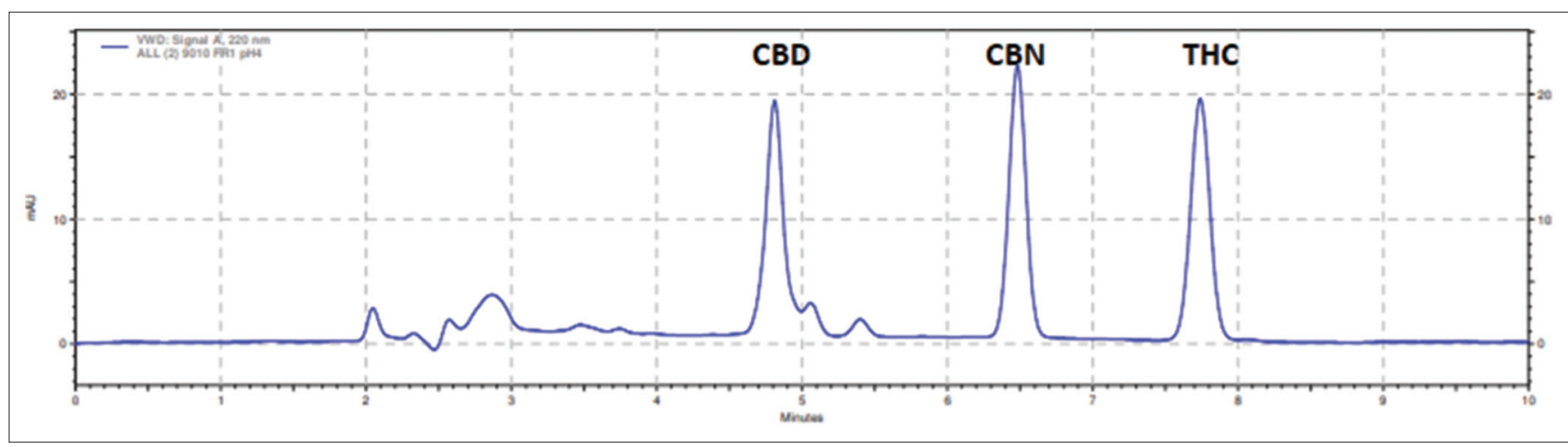

Fig. 12: Chromatogram produced using phosphate buffer (pH 4) and acetonitrile (10:90 v/v); detection wavelength $220 \mathrm{~nm}$; flow rate $1 \mathrm{~mL} / \mathrm{min}$

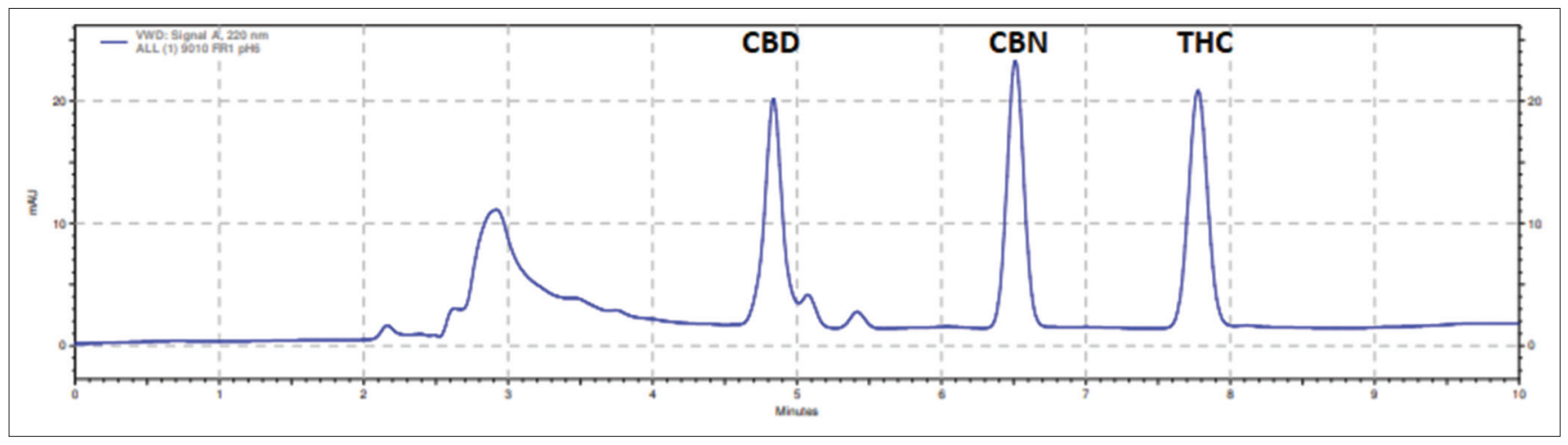

Fig. 13: Chromatogram produced using phosphate buffer (pH 6) and acetonitrile (10:90 v/v); detection wavelength $220 \mathrm{~nm}$; flow rate $1 \mathrm{~mL} / \mathrm{min}$ 


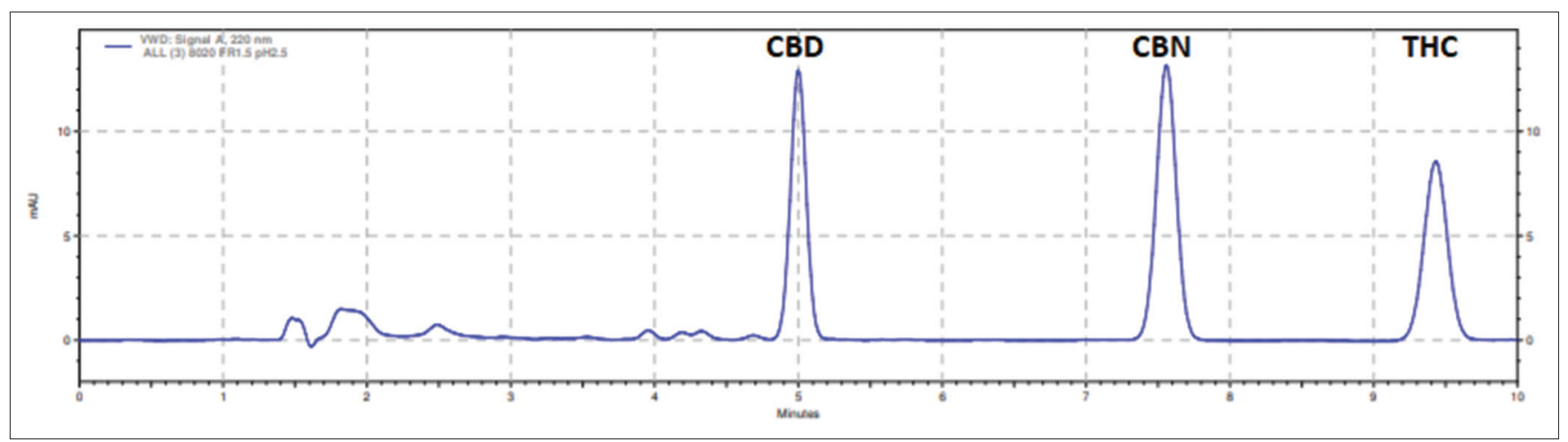

Fig. 14: Chromatogram produced using phosphate buffer $(\mathrm{pH} 2.5)$ and acetonitrile $(20: 80 \mathrm{v} / \mathrm{v})$; detection wavelength $220 \mathrm{~nm}$; flow rate $1.5 \mathrm{~mL} / \mathrm{min}$

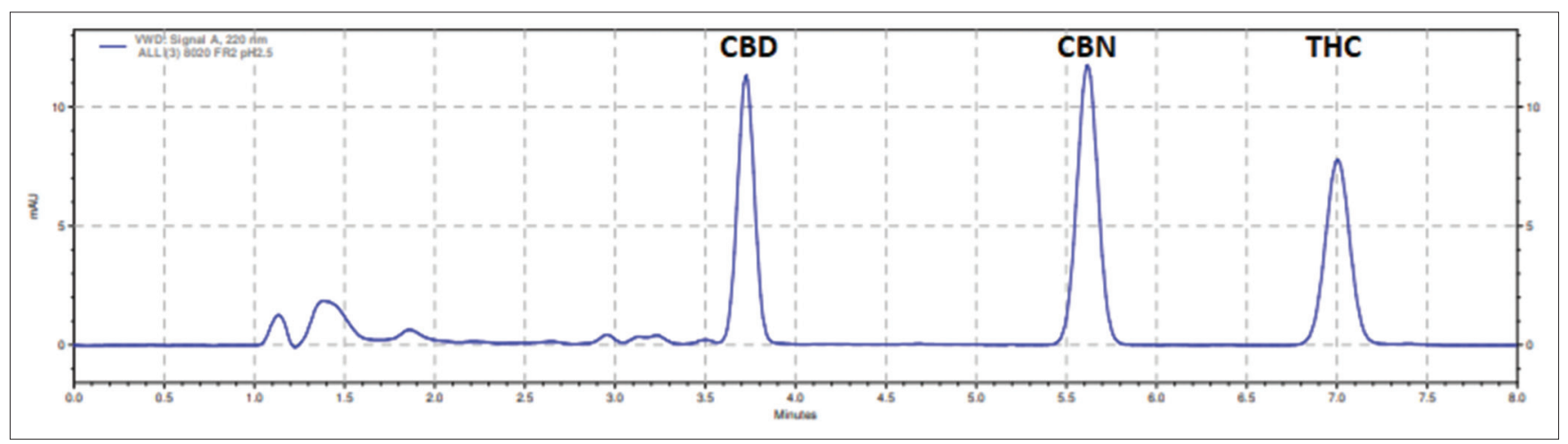

Fig. 15: Chromatogram produced using phosphate buffer (pH 2.5) and acetonitrile $(20: 80 \mathrm{v} / \mathrm{v})$; detection wavelength $220 \mathrm{~nm}$; flow rate $2 \mathrm{~mL} / \mathrm{min}$

$220 \mathrm{~nm}[39]$. CBD and CBN have higher absorptivity than THC at the selected wavelength for detection which could be due to a greater degree of conjugation within the molecule.

Although affecting the baseline, increasing the $\mathrm{pH}$ of the buffer did not affect peak size, shape, or order of elution of the cannabinoids, and this finding is in agreement with the study conducted by Hazekamp et al. [39]. At a pH lower than their pKa, the three cannabinoids were present in their protonated form and would have been present in their unprotonated form at $\mathrm{pHs}$ higher than their $\mathrm{pKa}$. Conversion of analytes from a protonated to an unprotonated form will probably cause shifts in chromatograms due to changes in the amounts of the two forms. The use of a buffer with a higher $\mathrm{pH}$ is not usually recommended in RP-HPLC analyses as this can result in solubilization of the silica support present in the column [15].

When larger volumes of acetonitrile were used, the retention time decreased but peak shape was compromised when mobile phases containing $90 \%$ acetonitrile were used. As larger volumes of organic modifier were used, there is less interaction of the three cannabinoids with the stationary phase resulting in quick elution, probably due to a shift in the partition coefficient which favors the mobile phase having larger amounts of acetonitrile. Buffering capacity could have been lost at higher percentages of acetonitrile in the mobile phase and having a buffer with a stronger concentration might counteract this [15].

Increasing the flow rate resulted in a decrease in total retention time for the three cannabinoids without a compromise in resolution. Having chromatographic methods which are quick are useful when conducting high throughput analyses [6]. Although changing the temperature did not result in any change in peak size, shape, and retention time, higher temperatures were not used so as to maintain the analytical procedure relatively energy efficient.

\section{CONCLUSION}

A rapid and easy to follow HPLC technique using readily-available instrumentation to separate and determine concentrations of THC, CBD, and CBN in a mixture of cannabinoids in methanol are described. Different amounts of acetonitrile result in differences in retention time, peak size, and shape for THC, CBD, and CBN. The best chromatograms in terms of peak shape, peak size, baseline characteristics, and retention time are given when using $80 \%$ acetonitrile with a buffer $\mathrm{pH}$ of 2.5 and $\mathrm{pH} 3$ at a flow rate of $2 \mathrm{~mL} / \mathrm{min}$, detected at a wavelength of $220 \mathrm{~nm}$.

The Expert Committee on Drug Dependence proposed that pure CBD preparations should not be scheduled within international drug control conventions [40]. This method would be useful to meet the recommendations of the United Nations Commission on narcotic drugs for rescheduling of cannabis. A simple and rapid technique using instrumentation which is available in most laboratories, such as the one proposed, can be validated and applied to separate and determine cannabinoids such as THC in CBD preparations.

\section{AUTHOR CONTRIBUTIONS}

- Ms. Eva Tejada- Main researcher

- Dr. Janis Vella Szijj- corresponding author, reviewer, and project supervisor

- Ms. Miriana Cachia- contributed in laboratory work and review

- Ms. Pauline Falzon- contributed in laboratory work and review

- Prof. Lilian.M.Azzopardi- head of department and reviewer

- Prof. Anthony Serracino Inglott-project supervisor.

\section{REFERENCES}

1. Nahar L, Onder A, Sarker SD. A review on the recent advances in HPLC, UHPLC and UPLC analyses of naturally occurring cannabinoids (2010-2019). Phytochem Anal 2020;31:413-57. 
2. Nikolin B, Imamović B, Medanhodzić S, Sober M. High performance liquid chromatography in pharmaceutical analyses. Bosn J Basic Med Sci 2004;4:5-9.

3. Rafferty JL, Siepmann JI, Schure MR. Mobile phase effects in reversed-phase liquid chromatography: A comparison of acetonitrile/ water and methanol/water solvents as studied by molecular stimulation. J Chromatogr A 2011;1218:2203-13.

4. Wilson RE, Groskreutz SR, Weber SG. Improving the sensitivity, resolution and peak capacity of gradient elution in capillary liquid chromatography with large-volume injections by using temperatureassisted on-column solute focusing. Anal Chem 2016;88:5112-21.

5. Locatelli M, Melucci MD, Carlucci G, Locatelli C. Recent HPLC strategies to improve sensitivity and selectivity for the analysis of complex matrices. Instrum Sci Technol 2012;40:112-37.

6. Vella J, Busuttil F, Bartolo NS, Sammut C, Ferrito V, SerracinoInglott A, et al. A simple HPLC-UV method for the determination of ciprofloxacin in human plasma. J Chromatogr B Analyt Technol Biomed Life Sci 2015;989:80-5.

7. Venn RF. Principles and Practice of Bio-Analysis. $2^{\text {nd }}$ ed. London: Taylor and Francis; 2005.

8. Muchohi SM, Thuo N, Karisa J, Muturi A, Kokwaro GO, Maitland K. Determination of ciprofloxacin in human plasma using highperformance liquid chromatography coupled with fluorescence detection: Application to a population pharmacokinetics study in children with severe malnutrition. J Chromatogr B 2011;879:146-52.

9. Yang Y. High-Temperature Liquid Chromatography, LcGC North America; 2008. Available from: https://www.researchgate.net/ publication/269874595 high-temperature liquid chromatography. [Last accessed on 2020 Oct 05].

10. Wenclawiak BW, Sascha G, Tuetenberg T. High-temperature liquid chromatography. Anal Lett 2008;41:1097-105.

11. Hendriks G. Theoretical models in LC based bioanalytical method development. J Pharm Biomed Anal 2009;49:1-10.

12. Marques RM, Schoenmakers PJ. Modelling retention in reversed-phase liquid chromatography as a function of $\mathrm{pH}$ and solvent composition. J Chromatogr A 1992;592:157-82.

13. Galaon T, David V. The influence of mobile phase $\mathrm{pH}$ on the retention and selectivity of related basic compounds in reversed-phase liquid chromatography. Rev Roum Chim 2012;57:131-40.

14. Mifsud-Buhagiar L, Scorpiniti M, Bartolo NS, Szijj JV, Ferrito V, Serracino-Inglott A, et al. Implications of mobile phase composition and $\mathrm{pH}$ of the chromatographic separation of amitriptyline and its metabolite nortriptyline. Int J Pharm Pharm Sci 2018;10:132-8.

15. Vella J, Mifsud M, Bartolo NS, Ferrito V, Serracino-Inglott A, Azzopardi LM, et al. The combined effects of $\mathrm{pH}$ and acetonitrile composition on the separation of two lincosamide antibiotics. Asian J Pharm Clin Res 2014;7:96-100.

16. Ahuja A, Rasmussen H. HPLC Method Development for Pharmaceuticals. Amsterdam: Elsevier, Academic Press; 2007.

17. Sanli S, Sanli N, Alsancak G. Spectrophotometric determination of acidity constants of some macrolides in acetonitrile-water binary mixtures. Acta Chim Slov 2010;57:980-7.

18. Deidda R, Avohou TH, Orlandin S, Baronti R, Pasquini B, Furlanetto S, et al. Analytical quality by design: Development and control strategy for a RP-HPLC method implemented in routine to evaluate the cannabinoids content in Cannabis olive oil extracts. J Pharm Biomed Anal 2019;166:326-35.

19. de Petrocellis L, Ligresti A, Moriello AS, Allarà M, Bisogno T, Petrosino S, et al. Effects of cannabinoids and cannabinoid-enriched Cannabis extracts on TRP channels and endocannabinoid metabolic enzymes. Br J Pharmacol 2011;163:1479-94.

20. Baron EP. Comprehensive review of medicinal marijuana, cannabinoids, and therapeutic implications in medicine and headache: What a long strange trip it's been. Headache 2015;55:885-916.

21. Pellati F, Borgonetti V, Bighenti V, Biagi M, Benvenuti S, Corsi S. Cannabis sativa L. and nonpsychoactive cannabinoids: Their chemistry and role against oxidative stress, inflammation, and cancer. Biomed Res Int 2018;2018:1691428

22. Zuardi AW. History of Cannabis as a medicine: A review. Braz J Psychiatry 2006;28:153-7.

23. Eliott J, Deirdre D, Clifford T, Coyle D, Potter B, Skidmore B, et al. Cannabis for pediatric epilepsy: Protocol for a living systematic review. Syst Rev 2018;7:95.

24. Klumpers LE, Thacker DL. A brief background on Cannabis: From plant to medical indications. J AOAC Int 2019;12:412-20.

25. Lafaye G, Karila L, Blecha L, Benyamina A. Cannabis, cannabinoids and health. Dialogues Clin Neurosci 2017;19:309-16.

26. Zgair A, Wong JC, Sabri A, Fischer PM, Barrett DA, Constantinescu CS, et al. Development of a simple and sensitive HPLC-UV method for the simultaneous determination of cannabidiol and $\Delta$ 9-tetrahydrocannabinol in rat plasma. J Pharm Biomed Anal 2015;114:145-51.

27. Gallo-Molina AC, Castro-Vargas HI, Garzón-Méndez WF, Ramirez JA, Monro ZJ, King JW, et al. Extraction, isolation and purification of tetrahydrocannabinol from the Cannabis sativa L. plant using supercritical fluid extraction and solid phase extraction. J Supercrit Fluids 2019;146:208-16.

28. Jamwal R, Topletz AR, Ramratnam B, Akhlaghi F. Ultra-high performance liquid chromatography tandem mass-spectrometry for simple and simultaneous quantification of cannabinoids. J Chromatogr B Analyt Technol Biomed Life Sci 2017;1048:10-8

29. Mazina J, Spiljova A, Vaher M, Kaljurand M, Kulp M. A rapid capillary electrophoresis method with LED-native fluorescence detection for analysis of cannabinoids in oral fluid. Anal Methods 2015;7:7741.

30. ChEMBL; 2018. Available from: https:/www.ebi.ac.uk/chembl/ compound_report_card/chembl74415. [Last accessed on 2020 Oct 06].

31. Cas MD, Casagni E, Saccardo A, Arnoldi S, Young C, Scotti S, et al. The Italian panorama of Cannabis light preparation: Determination of cannabinoids by LC-UV. Forensic Sci Int 2020;307:110-3.

32. Elkins AC, Deseo MA, Rochfort S, Ezenieks V, Spangenberg G. Development of a validated method for the qualitative and quantitative analysis of cannabinoids in plant biomass and medicinal Cannabis resin extracts obtained by super-critical fluid extraction. J Chromatogr B Analyt Technol Biomed Life Sci 2019;1109:76-83.

33. Burnier C, Esseiva P, Rouseel C. Quantification of THC in Cannabis plants by fast-HPLC-DAD: A promising method for routine analyses. Talanta 2019;192:135-41.

34. Mandrioli M, Tura M, Scotti S, Gallina T, Toschi T. Fast detection of 10 cannabinoids by RP-HPLC-UV method in Cannabis sativa L. Molecules 2019;24:2113.

35. Bettiol A, Lombardi N, Crescioli G, Maggioni V, Gallo E, Mugelli A, et al. Galenic preparations of therapeutic Cannabis sativa differ in cannabinoids concentration: A quantitative analysis of variability and possible clinical implications. Front Pharmacol 2018;9:1543.

36. Citti C, Linciano P, Forni F, Vandelli MA, Gigli G, Laganà A, et al. Analysis of impurities of cannabidiol from hemp. Isolation, characterization and synthesis of cannabidibutol, the novel cannabidiol butyl analog. J Pharm Biomed Anal 2019;175:112752.

37. Križman M. A simplified approach for isocratic HPLC analysis of cannabinoids by fine tuning chromatographic selectivity. Eur Food Res Technol 2020;2:315-22.

38. Namdar D, Mazuz M, Ion A, Koltai H. Variation in the compositions of cannabinoid and terpenoids in Cannabis sativa derived from inflorescence position along the stem and extraction methods. Ind Crops Prod 2018;113:376-82.

39. Hazekamp A, Peltenburg A, Verpoorte R, Giroud C. Chromatographic and spectroscopic data of cannabinoids from Cannabis sativa L. J Liq Chromatogr Relat Technol 2005;28:2361-82.

40. United Nations Office on Drugs and Crime. WHO Scheduling Recommendations on Cannabis and Cannabis-Related Substances; 2020. Available from: https://www.unodc.org/unodc/en/commissions/ $\mathrm{cnd} /$ mandate functions/current-scheduling-recommendations.html. [Last accessed on 2020 Oct 26]. 